\title{
Teaching NeuroImage: Concomitant Brain and Spine Lesions due to Multiple Nutritional Deficiencies
}

Qasem N. Alshaer, MD, and Rocio Garcia-Santibanez, MD

Neurology ${ }^{\circledR}$ 2021;97:e1464-e1465. doi:10.1212/WNL.0000000000012186

Figure 1 Brain MRI With Splenium of the Corpus Callosum Lesion
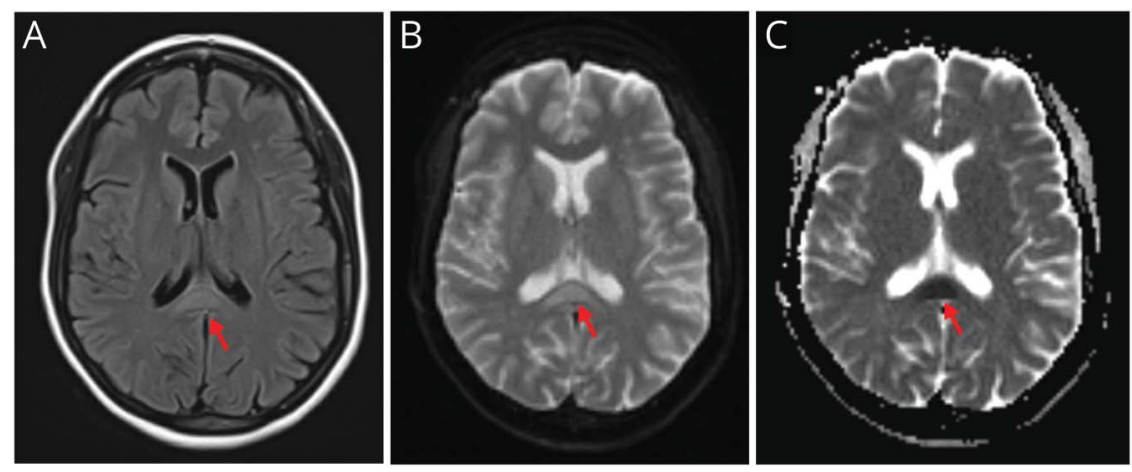

(A) Hyperintense T2/fluid-attenuated inversion recovery signal and (B, C) fluid restriction on diffusion-weighted imaging/apparent diffusion coefficient.

A 28-year-old vegetarian woman with pernicious anemia developed progressive leg spasticity and psychosis leading to food paranoia and severe malnutrition. She presented with encephalopathy, anemia, hypoalbuminemia, and severe deficiency of zinc and vitamins $\mathrm{B}_{1}, \mathrm{~B}_{6}$, and $\mathrm{B}_{12}$. MRI revealed a lesion of the splenium of the corpus callosum (figure 1) and spinal cord changes (figure 2). This case shows a combination of findings associated with vitamin deficiencies: corpus callosum (B complex, Marchiafava-Bignami disease $)^{1}$ and spinal cord $\left(\mathrm{B}_{12}\right.$, subacute combined degeneration $)^{2}$ Primary demyelinating, autoimmune, and metabolic disorders $(\mathrm{Cu}$, vitamin E) were ruled out given the clinical context and workup. After treatment, the psychosis resolved; the spasticity and weakness improved.

\section{Study Funding}

The authors report no targeted funding.

\section{Disclosure}

The authors report no disclosures relevant to the manuscript. Go to Neurology.org/ $\mathrm{N}$ for full disclosures.

\section{Correspondence}

Dr. Alshaer

qalshae@emory.edu

\section{MORE ONLINE}

Teaching slides

links.lww.com/WNL/

B417 
Figure 2 Spine MRI Shows Involvement of the Posterior Cord (Dorsal Column) and the Lateral Tracts (Including the Corticospinal Tracts) Spanning the Entire Cord
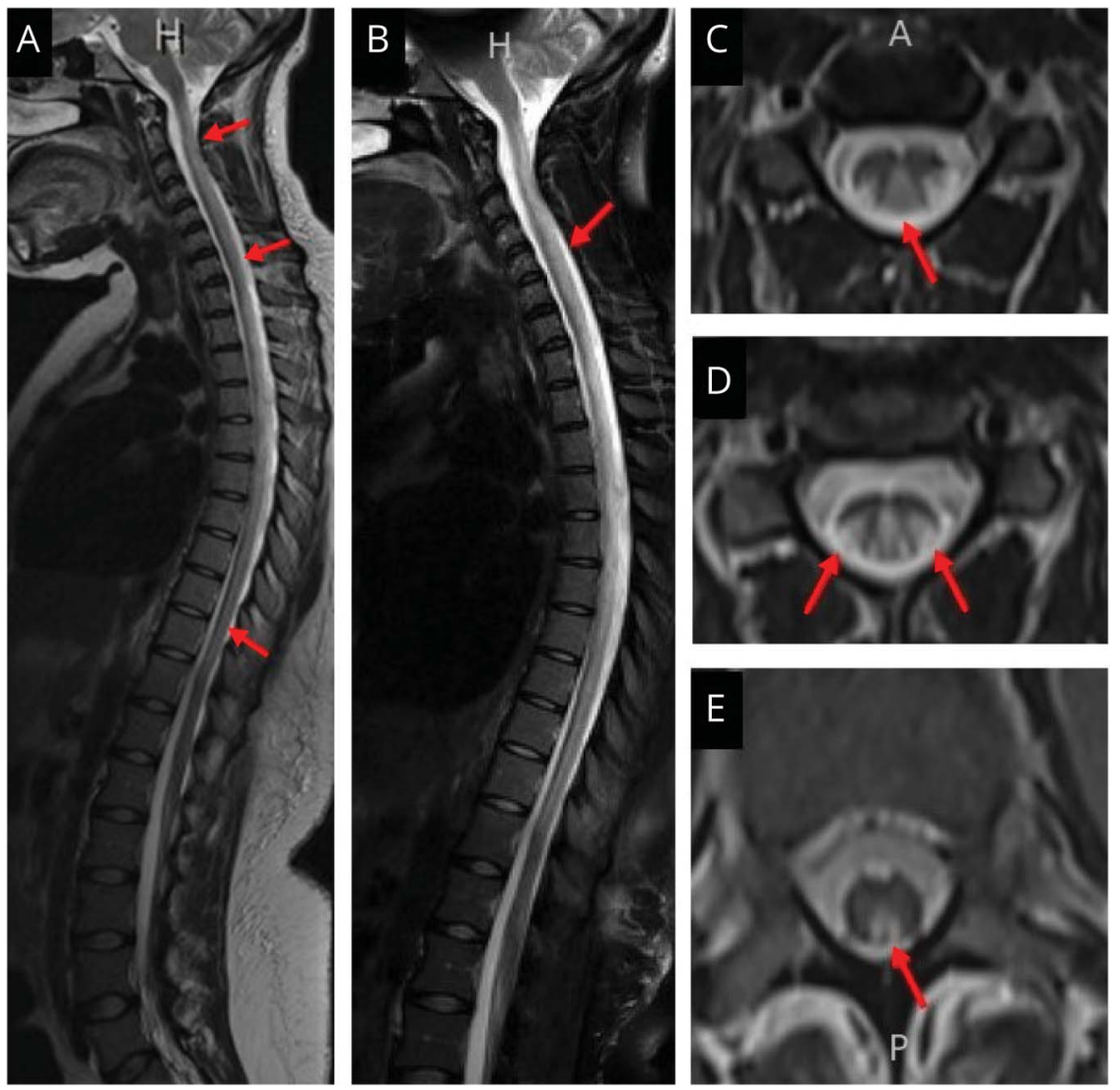

$(A, B)$ Sagittal section demonstrates the characteristic "inverted V sign" at the level of the cervical spine $(C, D)$ and the lumbar spine $(E)$.

Appendix Authors

\begin{tabular}{|c|c|c|}
\hline Name & Location & Contribution \\
\hline $\begin{array}{l}\text { Qasem N. } \\
\text { Alshaer, MD }\end{array}$ & $\begin{array}{l}\text { Department of Neurology, } \\
\text { Emory University, Atlanta, GA }\end{array}$ & $\begin{array}{l}\text { Writing the report, acquiring } \\
\text { and preparing the scans }\end{array}$ \\
\hline $\begin{array}{l}\text { Rocio Garcia- } \\
\text { Santibanez, } \\
\text { MD }\end{array}$ & $\begin{array}{l}\text { Department of Neurology, } \\
\text { Emory University, Atlanta, } \\
\text { GA }\end{array}$ & $\begin{array}{l}\text { Conceptualizing and editing } \\
\text { the report }\end{array}$ \\
\hline
\end{tabular}

\section{References}

1. Starkey J, Kobayashi N, Numaguchi Y, Moritani T. Cytotoxic lesions of the corpus callosum that show restricted diffusion: mechanisms, causes, and manifestations. RadioGraphics. 2017;37(2):562-576.

2. Schwendimann RN. Metabolic and toxic myelopathies. Continuum. 2018;24(2): $427-440$. 


\section{Neurology}

\section{Teaching NeuroImage: Concomitant Brain and Spine Lesions due to Multiple Nutritional Deficiencies}

Qasem N. Alshaer and Rocio Garcia-Santibanez

Neurology 2021;97;e1464-e1465 Published Online before print May 13, 2021

DOI 10.1212/WNL.0000000000012186

\section{This information is current as of May 13, 2021}

\section{Updated Information \&} Services

References

Subspecialty Collections

Permissions \& Licensing

Reprints including high resolution figures, can be found at: http://n.neurology.org/content/97/14/e1464.full

This article cites 2 articles, 0 of which you can access for free at: http://n.neurology.org/content/97/14/e1464.full\#ref-list-1

This article, along with others on similar topics, appears in the following collection(s):

All Clinical Neurology

http://n.neurology.org/cgi/collection/all_clinical_neurology All Spinal Cord

http://n.neurology.org/cgi/collection/all_spinal_cord

MRI

http://n.neurology.org/cgi/collection/mri

\section{Nutritional}

http://n.neurology.org/cgi/collection/nutritional

Information about reproducing this article in parts (figures,tables) or in its entirety can be found online at:

http://www.neurology.org/about/about_the_journal\#permissions

Information about ordering reprints can be found online:

http://n.neurology.org/subscribers/advertise

Neurology ${ }^{\circledR}$ is the official journal of the American Academy of Neurology. Published continuously since 1951, it is now a weekly with 48 issues per year. Copyright () 2021 American Academy of Neurology. All rights reserved. Print ISSN: 0028-3878. Online ISSN: 1526-632X.

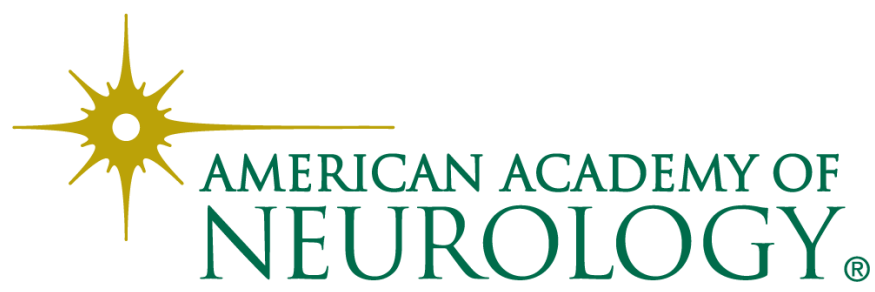

